\title{
National scarce skills within the Professional Chef's sector in South Africa
}

\author{
*Rishidaw Balkaran, Andrea Giampiccoli \\ Durban University of Technology \\ *rishi@dut.ac.za
}

\begin{abstract}
Since 1994, South Africa has witnessed an exceptional growth of the tourism sector. The hospitality sector is following a same positive trend however, there is not an appropriate growth of its human resources. South Africa, as many other countries, suffers a skills shortage of catering employees such as executive chefs and cooks. In addition, the historical context of South Africa has produced a specific skewed demographic picture of kitchen staff that now needs to be rebalanced. The skills shortage of kitchen staff could seriously affect the quality of service of the growing hospitality sector. This paper intends to investigate the context and problems related to kitchen staff shortages in South Africa. A literature review of factors such as low wages, unsociable and long hours will be outlined. Thereafter, the specific context of South Africa will be investigated. The specific history of the country has influenced also the hospitality (and kitchen staff) milieu, thus issues in the transformation of the sector will need to be put forward. The paper will conclude with some possible suggestion to decrease the skill shortage in kitchen staff in South Africa.
\end{abstract}

Keywords: South Africa, Hospitality, Tourism, skill development, chef

\section{Introduction}

The tourism sector has had global growth during the last 50 years(Telfer and Sharpley, 2008: 24). In South Africa the growth of tourism has also been exceptional since 1994 (the year of the first democratic election in South Africa) whenthe country rejoined the global context after the years of isolation. In this regard the South African Tourism(SAT, 2006: 12) 2005 Tourism Annual Report mentions that since 1994 tourism (foreign tourist arrivals) has increased by $100 \%$ in 11 years. The situation of domestic tourism seems more mixed due to specific economic constraints(SAT, 2012a: 8).The International Labour Organization (ILO, 2010: 4) mentions that the hotel, catering and tourism industry is a fast growing sector in global term. The food outlets sector followsa similar trend and also have witnessed major growth globally(ILO, 2010: 10).These few highlighted facts serve to introduce the issues relevant to the needs for staff in the hospitality industry. The relationship between the growth of the tourism and hospitality sectors and the skill shortage within the same industries has been debated and mostly agreed on (Maumbe \& Van wyk, 2011: 366). In South Africa the tourism sector has been identified as fundamental economic sector that should drive "economic growth, upliftment of local communities, and transformation" (Maumbe \& Van wyk, 2011: 366). Nevertheless, at the same time, Maumbe and Van wyk (2011: 366) mention that "achieving this tourism-led development is hampered by the critical shortage of skills which are central to the development of local communities and the country." The matters related to skill shortage in the hospitality sector are relevant in the present academic debate (Marchante et al., 2006: 791). Therefore, the aim of this paper is to investigate, with specific reference to South Africa, the issues and problems around the shortage of skilled personneland transformation within the hospitality sector with specific reference to the kitchen brigade.

\section{Literature Review}

The kitchen brigade skills shortage is a worldwide phenomenon. Studies related to issues of skills shortage of chefs has been done in various countries, such as Australia (Robinson et al. 2010), United Kingdom (Pratten \& O'Leary, 2007), and Spain (Marchante et al., 2006).Skills shortage in the hospitality industry is shared by both developed and developing countries (Goldsmith \& Mohd Zahari, 1994: 28; Robinson et al., 2010: 483). Assembling from other authors Baum (2002: 347) indicates a list of reasons for the hospitality industry'slow attractiveness such as the propensity towards low wages (but not when skills shortages reverse it), predominance of unsocial working hours, weak career opportunities, high turnover, and male biases in higher positions. Based on literature Marchante et al. (2006: 791) follow similar lines and indicate that skills shortages and hard-to-fill vacancies in the hospitality industries has been seen correlated to the hospitality sector characteristics. Studies focusing on chefs in the hospitality 
industry mention that there is labour shortage and the sector struggle to retain qualified personnel(Pratten, 2003: 241; Pratten \& O'Leary, 2007: 69).The International Labour Organization (ILO) while proposing various similar working conditions in the hospitality sector points out that these are country specific(ILO, 2010: 14). Despite these specific chefs jobs matters Pratten and O'Leary (2007: 76) importantly suggests that the chefs leave the profession "does not necessarily mean work dissatisfaction." At the same time if the working conditions cannot be changed then the educational system leading to the profession of chef needs to be revisited (Pratten \& O'Leary, 2007: 76).

Specific contexts of skill shortage can have a positive role (at least for the people that can exploit the context). Low wages in the hospitality sector has been mentioned (Baum, 2002: 347; Pratten, 2003: 239; Marchante et al., 2006: 791; Pratten \& O'Leary, 2007: 69). However, Lashley (2009: 349) indicated that chef wage increaseshave occurred in England according to a 2002 report. The growth of the hospitality industry in developing countrieshas led to increased job competition and an increment in salary and improved working conditions through emphasizing the need for qualified personnel(Goldsmith \& Mohd Zahari, 1994: 28). At the same time skills shortages in the professional chefs' sector can lead to recruitment of overseas professional chefs as it in the case of Malaysia (Goldsmith \& Mohd Zahari, 1994). Lashley (2009: 349)remarks that cooking skills vary from simple capabilities to more difficult ones and it is specifically the high level "cuisine cooking" that endorses better pay and ultimately an attraction to the industry but that requires greater skills and specific education and training. On the reverse side of highly qualified cooking capacities, matters related to de-skillingis present in the sector(Baum, 2002: 351; Lashley, 2009: 349). However, de-skilling does not eliminate or contradict the need for skilled chefs. Thus, although the "the global effect of 'dumbing down' average skills levels in hospitality and tourism, it is difficult to argue that they have eliminated demand for higher order skills within other sectors of the industry"(Baum, 2002: 351).These matters suggest that while general skillsrequirements seem to promotelower status of chefs/cooks (promoting less attractiveness to the industry) various skills including high-end skills are still required making training and education at all levels of the industry a necessity. Robinson and Barron (2007: 919) while recognizing that chefs are not immune, as other hospitality sector jobs, to conventionally perceive poor working conditions, they argue that de-skilling and standardization be seen as a contradiction to the understanding of a chef as a culinary artist. The return towards culinary 'authenticity' and 'home-cooked' food can also serve to favor high skills jobs even if it is a minor job (Lashley, 2009: 349). Another perspective on the de-skilling and low skill values normally associated with thehospitality sector is related to socio-cultural setting.This perspective is important because de-skilling is based within a framework that is managed within specific western cultural understandings. As such it "questions the validity of claims that hospitality is a work area of low skills" (Baum, 2002: 349).

The South African context: In South Africa the hospitality chamber "is estimated to include 28000 employers employing 290000 employees" (THETA no date-a: 10). Relevant data about the food and beverage subsector shows that between the first quarter of the year 2008 and the first quarter of the year 2009 total income has increased(THETA no date-a: 10). The role of tourism in South Africa and the close relationship between tourism development and skills shortages is supported by the Tourism, Hospitality and Sport Education and Training Authority (THETA):

"If]or tourism to be successfully prioritised by the country, it necessitates accurate and precise skills planning to effectively address its scarce and critical skills shortages. Only once these skills shortages have been eradicated will the tourism sector be able to maximise its contribution to the country's employment opportunities and GDP" (THETA no date-a: 5).

The relevance and growth of the tourism and hospitality sector has produced unmatched availability of needed human resources. The country needsqualified personnel and various initiatives has been advanced, such as the establishment of the THETA ${ }^{1}$ in 1998 (Moyle, 2008: 529). The chronic skills shortage in the South African tourism industry is located at middle management level and supervisory level while top management positions and operational positions do not suffer shortage of qualified people and junior level positions is somehow in the middle with no severe shortage (Moyle, 2008:530). The chef

\footnotetext{
${ }^{1}$ Kaplan (2004:224) argues that the "THETA has its origins in the Hospitality Industries Training Board (HITB), which was set up by, and to serve the training needs of the formal hospitality industry - the large hotel and restaurant chains" thus limiting the role that can have in the more informal and/or smaller tourism sector. In addition the performance and credibility of THETA has been questioned (see Moyle 2008).
} 
category has been identified with skills shortage (Moyle, 2008: 546). Specifically, THETA (2009:48) mentions chefs as a position where there is a "scarcity of qualified and experienced people". This specific shortage was already previously identified in 2005 (THETA no date-b: 7). A recent Sector Skills Plan: 2012/13of the Culture, Arts, Tourism, Hospitality and Sport Sector Education and Training Authority (CATHSSETA) valid for the period 2012/13-2015/16 indicates, amongst other issues, that many chefs will retire in the next few years and their replacement will be difficult (CATHSSETA 2012: 33, 35, 40, 42).

The specific attention to African chefs and cooks is relevant in this context.Since 1994 South Africa's major concern was the need for social-economic transformation of the country. THETA (no date-b: III) indicates that the tourism industry has significantly grown in South Africa since the 1994 elections and that the tourism growth will contribute to economic transformation. In the tourism sector the specific framework of transformation, the tourism Black Economic Empowerment (BEE) scorecard, has been developed (Maumbe \& Van Wyk, 2008: 117). Transformation of the tourism industry is slow. Specifically, the hospitality sector has been noted to be one of the weak implementers of BBE policies(Tangri \& Southall, 2008: 702).THETA (no date-a: 48) supported the same proposing "there is a scarcity of both chefs but more specifically black chefs in the tourism sector."Looking at industry transformation, which is specific to South Africa, it is relevant to note that the same document (CATHSSETA, 2012: 54)mentions that "74\% of Chefs are African employees, which is extremely positive to note and is indicative of the transformation of this occupation" However, the document (CATHSSETA, 2012: 54)further mentions that most African held positions are juniorsuggesting that improvement is required.Whilst tourism skills development can serve as a catalyst to transformation and poverty alleviation the fragmented approach to tourism skills development can jeopardize tourism development and transformation. (Kaplan, 2004: 217).

More training opportunities are needed, especially for previously disadvantaged individuals, if both skill shortages and transformation agendasare to be achieved. In this regard the National Department of Tourism (NDT) and the South African Chefs Association (SACA) launched the National Youth Chefs Training Programme (NYCTP) pilot project in 2011 which make effort to address the skills shortage and contribute to poverty alleviation (SAT, 2012b). However, although a required component to foster skills development, specific training is not enough. The lack is not in the training providers but in the 'training' structure and components.Whilst, the training providers are sufficiently qualified, the present qualifications and programmes need to be diverse and appropriately developed. For courses and programmes to be truly effective a mentoring period is essential(CATHSSETA, 2012: 33; THETA no datea: 6).These issues are also suggested by (Billingham no date)arguing thatformal training and in-house training should be combined to work effectively to 'discover' and train potential chefs. It is important to note that thechefs' career can have an informal initial path. Thishowever can bring high achievement to the formal programme if properly nurtured. Importantly, entrance barriers to training programmes can be insurmountable by the South African youth. Cost and entry requirements are seen as a barrier in most cases$^{2}$ (Billingham no date: 46). A recent Impact Assessment of National Skills Development Strategy II(du Toit, 2012: X) study, which include the category of chefs and cooks, indicates that very few were accredited courses. The required level of entrance can be arguedto be necessary (or at least decreased) in relation to the chef profession. The informal career path to be nurtured has been also recognised. Illiteracy should be tackled with specific programmes such as ABET however it should not exclude $a$ priori a person to enter the chef profession. Billingham (no date: 50) mentions that practical skills are very relevant in the chefs profession and the absence of formal qualificationsor illiteracy should not be seen as a barrier to the employees aspirations.

\section{Conclusion and Recommendations}

A shortage of skills in the catering sector is dominant in much of the world and South Africa is not immune to this trend.In addition the specific South African context presents the need for industry transformation. There is no lack of institutions that offer hospitality qualifications but entrance requirements and cost prevent many from accessing most of them. Poor people if not properly supported remain excluded from the formal education towards a 'chef-related' qualification as cost to attain such

\footnotetext{
${ }^{2}$ To note however that the government Further Education and Training colleges offer Hospitality qualifications for people without Matric (high school qualification) and it pays most of the costs incurred. Most of the schools that offer hospitality and/or professional cookery qualifications are, however, too costly for most South Africans.
} 
qualification/s are out of reach of most people. South Africa does not have a culinary degree at the university level that could serve if properly subsidised by Government/ Business entities to facilitate the inclusion of poor people in the chef's profession. This possible new qualification on Culinary Art at University level should focus more on specific culinary skills and other kitchen requirements compared to the more 'general' hospitality management programmes. It isrecommended that South African Universities should offer Culinary Arts qualifications based on the following grounds:

- South Africa needs qualified chefs;

- Whilst there are a number of schools, or colleges (public and private) offering various qualifications in cookery,there are no offerings in the Culinary Arts at university level in South Africa;

- Globally there are various universities that offer qualifications related to culinary studies;

- A University qualification in Culinary Art could attract a number of people passionate about the cooking profession but are willing to have a university qualification instead of college or other school qualification;

- Subsidies should be available for the new qualification in the Culinary Arts;

- Entry requirements should be strategically structured to allow easy access to people with lower entry requirements, with relevant bridging programmes, and recognition of previous practical experience;

- Extended periods of internship with reasonable remuneration should be included in the new qualification.

Following Kaplan (2004: 217)it is possible to suggest that the hospitality sectorcould contribute to promote poor people benefits from the industry and promote industry transformation nevertheless there is the need for a more coordinated and structured framework and strategies to address skills shortages and its possible positive impacts. Fundamentally, poor people do not have enough financial resources to access proper qualifications and these qualifications often have high entry barriers for people with weak formal educational backgrounds. In this context, the State should be seen as a facilitator to providing the financial means and a specific structured qualification with a more flexible and custom structured entry requirement to enhance access of poor people.

\section{Reference}

Baum, T. (2002). Skills and training for the hospitality sector: a review of issues. Vocational Education \& Training, 54(3), 343-364.

Billingham, S. no date. Another brick in the wall. Available: http://www.restaurant.org.za/downloads/butler/brick_in_wall.pdf (Accessed 2 July).

Cathsseta. (2012). Sector skills plan 2012/13. Johannesburg: Culture Arts Tourism Hospitality \& Sport Sector Education \& Training Authority.

du Toit, R. (2012). The NSF as a mechanism to address skills development of the unemployed in South Africa. Pretoria: Human Sciences Research Council

Goldsmith, A. \& Mohd Zahari, M. S. (1994). Hospitality education in Malaysia: filling the skill gap. International Journal of Contemporary Hospitality Management, 6(6), 27-31.

ILO. (2010). Developments and challenges in the hospitality and tourism sector. Geneva: International Labour Organization.

Kaplan, L. (2004). Skills development in tourism: South Africa's tourism-led development strategy. GeoJournal, 60, 217-227.

Lashley, C. (2009). The right answers to the wrong questions? Observations on skill development and training in the United Kingdom's hospitality sector. Tourism and Hospitality Research, 9(4), 340352.

Marchante, A. J., Ortega, B. \& Pagan, R. (2006). Determinants of skills shortages and hard-to-fill vacancies in the hospitality sector. Tourism Management, 27, 791-802.

Maumbe, K. C. \& Van wyk, L. (2011). Addressing the Skills Shortage Problem of the South African Tourism and Hospitality Industry: An Evaluation of the Effectiveness of the 2007/2008 SA Host Training Program in the Western Cape Province. Urban Forum, 22, 363-377.

Maumbe, K. C. \& Van Wyk, L. J. (2008). Employment in Cape Town's lodging sector: opportunities, skills requirements, employee aspirations and transformation. GeoJournal, 73, 117-132.

Moyle, D. (2008). The growing skills crisis in the tourism sector. In: Kraak, A. and Press, K. eds. Human Resources Development Review 2008. Education, employment and skills in South Africa. Cape Town: Human Sciences Research Council, 528-554.

Pratten, J. (2003). The training and retention of chefs. International Journal of Contemporary Hospitality Management, 15(4), 237-242. 
Pratten, J. \& O'Leary, B. (2007). Addressing the causes of chef shortages in the UK. Journal of European Industrial Training, 31(1), 68-78.

Robinson, R. N. S., Arcodia, C. V., Tian, C. \& Charlton, P. (2010). Cookery-related employment vacancy advertisements and skills shortages. International Journal of Contemporary Hospitality Management, 22(4), 483-499.

Robinson, R. N. S. \& Barron, P. E. (2007). Developing a framework for understanding the impact of deskilling and standardisation on the turnover and attrition of chefs. Hospitality Management, 26, 913-926.

SAT. (2006). 2005 Annual Tourism Report. Johannesburg: South African Tourism Strategic Research Unit, South African Tourism.

SAT. (2012a). 2011 Annual Tourism Report. Johannesburg: South African Tourism Strategic Research Unit, South African Tourism.

SAT. (2012b). National youth chefs training programme a resounding success. Available: http://www.southafrica.net/za/en/news/entry/news-southafrica.net-national-youth-chefstraining-programme-a-resounding-s (Accessed 2 July 2013).

Tangri, R. \& Southall, R. (2008). The politics of Black Economic Empowerment in South Africa. Journal of Southern African Studies, 34(3), 699-716.

Telfer, D. J. \& Sharpley, R. (2008). Tourism and development in the Developing World. London: Routledge.

THETA. no date-a. Sector skill plan 2010/2011. Johannesburg: Tourism, Hospitality and Sport Education and Training Authority.

THETA. no date-b. Theta Sector Skills Plan 2005-2009 Johannesburg: Tourism, Hospitality and Sport Education and Training Authority. 